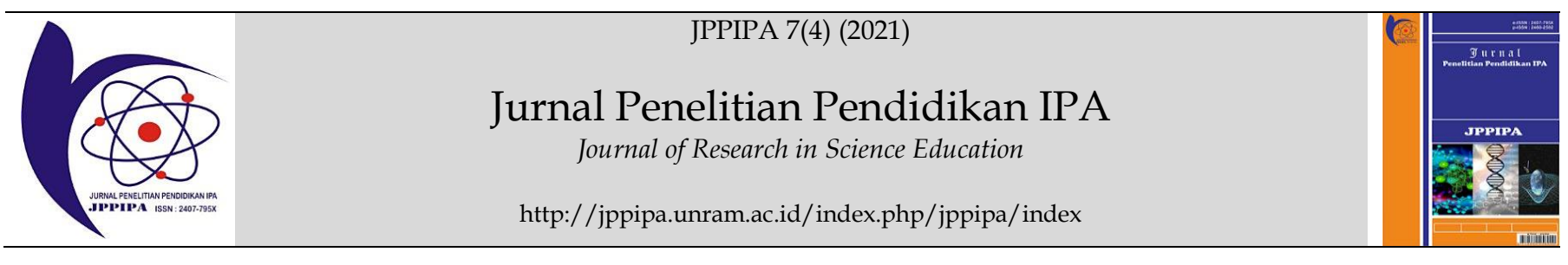

\title{
Profile of Problem-based Learning (PBL) Model Assisted by PhET to Improve Critical Thinking Skills of High School Students in Dynamic Electrical Materials
}

\author{
Nabila Rahmadita ${ }^{1}$, Husni Mubarok ${ }^{2}$, Binar Kurnia Prahani ${ }^{*}$ \\ ${ }^{1}$ Universitas Negeri Surabaya, Indonesia \\ ${ }^{2}$ National Taiwan University of Science and Technology, Taiwan
}

DOI: $\underline{0.29303 / \text { ippipa.v7i4.799 }}$

\section{Article Info}

Received: June 17th, 2021

Revised: September $8^{\text {th }}, 2021$

Accepted: October 8th, 2021

\begin{abstract}
This study discusses the implementation of problem-based learning (PBL) assisted by physics education technology (PhET) as a virtual laboratory to improve the critical thinking skills of high school students on dynamic electrical materials. The purposes of this research were to obtain the profile of students' critical thinking skills and the implementation of PBL assisted by PhET in senior high schools. This research method was a preliminary study with a qualitative descriptive analysis, written tests, student response questionnaires, and teacher interviews. The finding of students' critical thinking skills was categorized into three levels (low, moderate, and high). There are seventeen students in the low category, fifty-three students in the moderate category, and thirty students in the high category. The conclusion of this study revealed that students' critical thinking skills at the senior public school Surabaya were in the moderate category, and training questions were needed to improve students' critical thinking skills.
\end{abstract}

Keywords: Problem based learning; critical thinking; virtual labs; PhET

Citation: Rahmadita, N., Mubarok, H., \& Prahani, B. (2021). Profile of Problem-based Learning (PBL) Model Assisted by PhET to Improve Critical Thinking Skills of High School Students in Dynamic Electrical Materials. Jurnal Penelitian Pendidikan IPA, 7(4), 617-624. doi:https://doi.org/10.29303/jppipa.v7i4.799

\section{Introduction}

Physics is one of the natural science branches, which studies the formulas and theories in nature, including scientific events experienced by humans. Physics itself is part of the Natural Sciences, which have an empirical nature. Everything studied in physics results from observations about natural phenomena and natural phenomena (Rahayu, 2017).

According to Depdiknas (2003), the purpose of physics subjects for senior high school is to mastery the knowledge, concepts, and principles of physics and have knowledge of scientific skills and attitudes. From the objectives listed above, it can be seen that the physics learning process in secondary schools should be carried out with methods. Not only master knowledge, concepts, and principles, but students must also have scientific skills and attitudes. One of the skills in question is critical thinking skills.

Critical thinking skills are essential to be taught, trained as early as possible, and carried out continuously according to students' age and developmental stages so that students can observe various problems that may occur in learning activities and think of solutions to these problems. So that good learning outcomes can be realized, can overcome the problems of life that are passed at each stage of the development of students by finding solutions based on the experience that has been passed (Ismayawati et al., 2016).

According to (Qurniati et al., 2015), critical thinking skills require students to analyze their own thoughts to prove that students have found choices and can draw smart conclusions. Knowing critical thinking 
is very important and can determine the success of life, both in solving problems, making decisions, and being a supporter in developing broad knowledge. Meanwhile, according to (Latifa et al., 2017), critical thinking skills are processes and abilities involved in making rational decisions. Someone who thinks critically will always ask himself every time he faces a problem to determine the best decision. Based on this, one solution, according to the researcher, is to apply Problem Based Learning.

PBL is a learning approach that uses real-world problems as a context for students to learn about critical thinking and problem-solving skills. As well as to obtain the essence and problem-based learning is used to foster critical thinking in situations that lead to problems so that students can learn to solve problems. (Maryati, 2018).

PBL changes the learning process from teachercentered to student-centered, while teachers experience a change in role from being a source of knowledge to being a facilitator in gaining knowledge (Rositasari et al., 2014). The implementation of the problem-based learning model can train several thinking skills such as critical thinking, analyzing and solving complex, collaborative, and communicative problems verbally and in writing (Rosa \& Pujiati, 2016)

PBL is a learning model that involves participants' students solving problems through the stages of the scientific method. Thus, students can learn knowledge related to problems and at the same time have skills in solving problems. PBL is a learning process where the starting point of learning is based on problems that exist in everyday life. From these problems, students are required to study this problem based on new knowledge and practice gained (Maryati, 2018).

Based on the explanation above, the learning method that can improve critical thinking skills is the experimental method. In physics learning itself, the experimental method is one method that supports the PBL. Learning using PBL is one of the learning models with a scientific approach. In the selection of this learning model, it is suitable to be applied at the senior high school because the learning model is complex and requires critical thinking with good analytical skills. Through this PBL, students are required to be more active in solving problems. According to the opinion expressed by Ennis (Cahyono, 2017) which can be concluded that there is a relationship between critical thinking and solving problems.

The characteristics of this learning model are, using problems in life as something that students must learn to train, develop thinking skills and problemsolving skills, learn adult roles and make independent students. In PBL, a collaboration between students is needed to encourage research and discussion together to develop critical thinking skills and social skills. The application of the PBL model has been researched by several experts before. Al-Idrus et al. (2015) state that learning physics using a PBL model with cartoon videos can affect students' learning outcomes of physics.

The Zahara et al. (2015) study revealed that students learning physics using PhET media experienced had increased the learning outcomes and higher critical thinking skills than students with conventional models. PBL can improve learning outcomes and students' understanding of concepts significantly. In addition to having advantages that distinguish it from other models, PBL models also have drawbacks, namely not providing sufficient time for students to be deeply involved in learning. One way to overcome this is with the help of media, both technology-based and straightforward media. One of the media used in computer-based media that can provide convenience for students is PhET media, which is an interactive simulation media that invites students to learn. PhET is used to clarify the physics concept. The use of PhET makes it easier for teachers to deliver a lot of material in one place so that the use of time is more efficient. Besides using PhET media, the learning process feels more fun to watch, read, digest, and remember. The purpose of the study was to determine the students' critical thinking skills and the application of PBL in high school. Whether in school students are taught using the learning model PBL assisted by PhET simulation or not and whether students' critical thinking skills are good or not.

\section{Method}

This study used a preliminary study with qualitative descriptive analysis. The preliminary study is conducted to find the information needed by researchers to make the problem more precise. This research did not use hypothesis testing but used a descriptive research design. The results of this study will be used as consideration for improving the learning models and learning media that enhance students' critical thinking skills in senior high school.

This research was carried out by online learning at the senior public school Surabaya in $11^{\text {th }}$ grade. The total participant of this study was 100 students in four classes.

Three types of data were collected, namely written tests, student response questionnaires, and teacher interviews. According to Sugiyono (2017), data collection techniques are critical in research because the primary purpose of research is to obtain data. 
Written tests are test questions that contain questions that students must answer by providing written answers. The critical thinking ability test was developed from the five aspects of critical thinking skills that became the benchmark (Pradana et al., 2017). Therefore, in this study, researchers used a critical thinking skill test with dynamic electrical material, which consisted of twelve essay questions with each indicator consisting of three questions.

The questionnaire is a research instrument consisting of several questions aimed at gathering information from respondents. In this study, the questionnaire used aims to know about the learning process that students and teachers have carried out as well as students' perspectives on this learning model by presenting ten questions in a questionnaire that students will fill out.

Figure 1 shows the procedure for the flow of research methods regarding the profile of students' critical thinking skills at the senior high school and the implementation of the problem-based learning (PBL) learning model assisted by physics education technology (PhET) as a virtual laboratory to improve critical thinking skills in dynamic electrical materials.

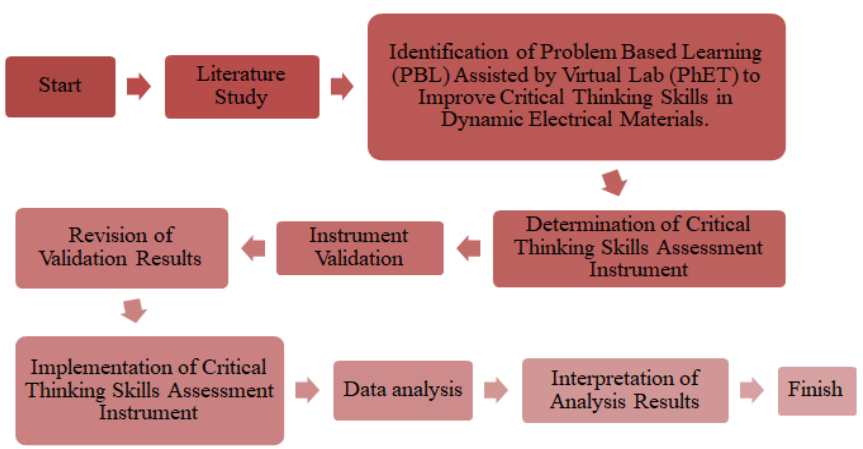

Figure 1. Research flowchart

\section{Result and Discussion}

\section{Critical thinking skills test}

This research was conducted using a written test instrument consisting of an essay test with twelve questions. Each indicator consists of three questions equipped with four critical thinking indicators: analysis, evaluation, interpretation, and inference (Facione, 2015). From the twelve questions, students are then asked to answer according to the existing problems, then for the assessment system of students' critical thinking skills based on the answers given. Students are expected to analyze questions, make conclusions, evaluate, and interpret based on the existing question instruments.

The assessment of critical thinking skills can be calculated based on the respondents' answers. Suppose the answer given is logical, complete, and systematic.
In this case, the respondent will get 5 points to answer full element. If the answer given meets only two elements, namely complete and logical, and systematic, the respondent will get 3 points. If the answer given meets only one element, the respondent will get a value of 1 point. If the answer given is wrong or does not meet the three elements, then the value obtained is 0 points.

\section{Interpretation}

Sekelompok siswa melakukan percobaan dan berhasil merangkai enam buah lampu identik dengan rangkaian di bawah ini :

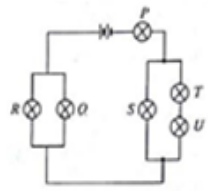

Dari rangkaian diatas, manakah lampu yang menyala palingredup adalah.... (Berikan alasan mengapa Anda memilih jawaban tersebut)

Figure 2. Question on interpretation indicator

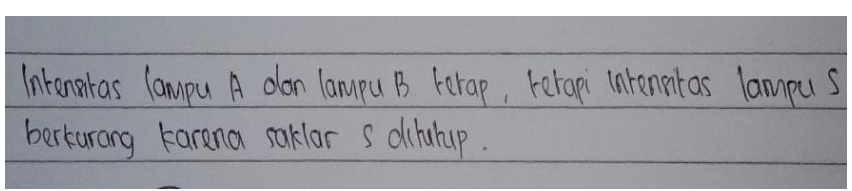

Figure 3. Students answers on the interpretation indicators

From the answers given, it can be seen that only one element is correct. Supposedly, the correct answer is that the intensity of lamps A and B is the same as bright, while the intensity of lamp $\mathrm{C}$ is the brightest, and the power in the circuit is fixed.

\section{Analysis}

Seekor burung merasa cukup aman berdiri pada kawat tegangan tinggi yang sedang mengalirkan arus listrik. Namun, jika kawat di antara kedua kakinya dipotong dan di antara ujung-ujung potongan disambungkan suatu lintasan kawat yang panjang kira-kira $200 \mathrm{~m}$, burung akan merasakan kejutan listrik. Mengapa?

Figure 4. Question on analysis indicator

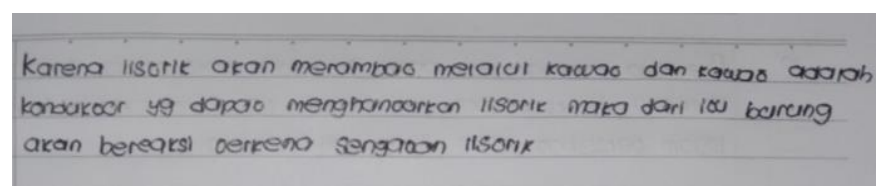

Figure 5. Students answer on the analysis indicator

From the answer given, it can be seen that it meets only one element, so the answer is wrong. The correct answer is that there are two conditions for an electric current to occur; there are potential differences and closed circuits. The two legs of the bird, namely 
point $A$ and point $B$, are at high voltage. Current flows through the air wire (conductor), and both legs of the bird have the same electric potential $\left(\mathrm{V}_{\mathrm{A}}=\mathrm{V}_{\mathrm{B}}\right)$, and this means the potential difference between points $\mathrm{A}$ and $\mathrm{B}$ is $V_{A}-V_{B}=0$. As a result, current does not flow through the bird's body, and birds do not burn under the highvoltage wire.

\section{Inference}

Dari percobaan tegangan (V) dengan kuat arus (I) pada resistor dihasilkan grafik V-I pada gambar dibawah.

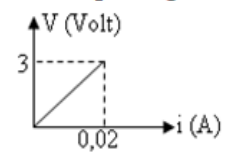

Jika $\mathrm{V}=4,5$ Volt, maka kuat arus yang mengalir sebesar... (Berikan kesimpulan dari grafik $\mathrm{V}$ terhadap I)

Figure 6. Question on inference indicator

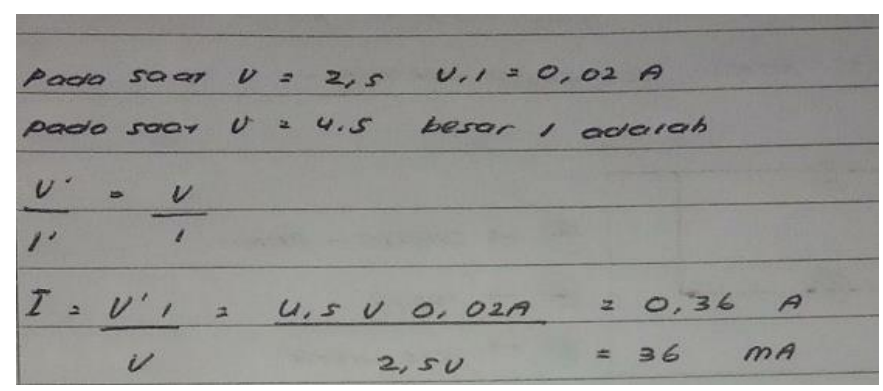

Figure 7. Students answer on the inference indicator

From the answers given, it can be seen if the answers do not meet the three elements. So that the answer is wrong, the correct answer should be if the formula used is V/I. Given that the voltage (V) is 3V, and current (I) is $0.02 \mathrm{~A}$. Then look for the value of resistor $(\mathrm{R})$ by means of $\mathrm{R}=\mathrm{V} / \mathrm{I}=3 / 0.02=150$ (150 is a fixed value). After finding the value of the resistor then calculating the value of I $(4,5 \mathrm{~V})$

$I=\frac{V}{R}=\frac{4,5 \mathrm{~V}}{150 \mathrm{n}}=0,03 \mathrm{~A}=30 \mathrm{~mA}$

Suppose the voltage $(\mathrm{V})$ is inversely proportional to the current (I) from the calculation value. So, the greater the value of the voltage and the smaller the value of the current.

\section{Evaluation}

Anda memiliki sebuah voltmeter DC dan sebuah amperemeter DC. Gambar dua rangkaian berbeda yang dapat Anda gunakan untuk mengukur hambatan sebuah resistor. Dan jelaskan perbedaan kedua rangkain itu ...

Figure 8. Questions on evaluation indicator

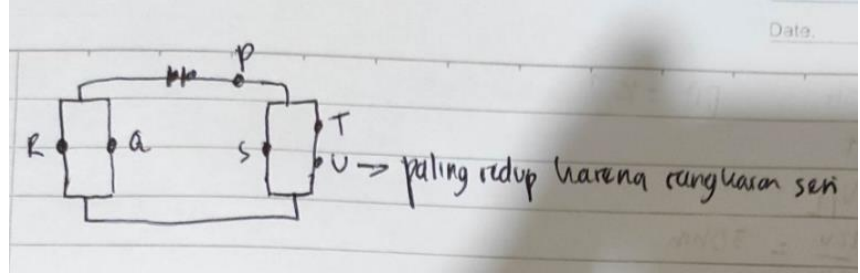

Figure 9. Students answer on the inference indicator

Based on Figure 6, the lowest value of the average critical thinking indicator is interference, while the highest is the analysis indicator. The thing that causes the interference indicator to get a low value is because the ability of students to draw conclusions is still relatively low. This is because students do not understand the questions, concepts, and equations given to the dynamic electricity material. Overall, there are 100 students. It was divided into three categories, namely, low, medium, and high. Where in the low category, there are 17 students, then in the medium category, there are 53 students, and in the high category, there are 30 students. From this description, it can be seen in the image below.

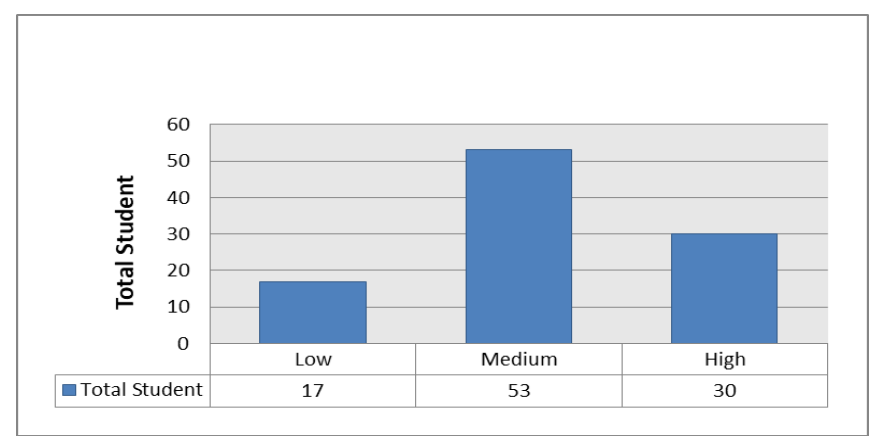

Figure 10. Categories of students' critical thinking skills

It can be seen from the picture above, where students who get grades in the low category are 17 students, then in the medium category as many as 53 students, and the high category as many as 30 students.

Differences in the critical thinking skills of male and female students can be calculated based on indicators of critical thinking skills. The results can be seen in the image below.

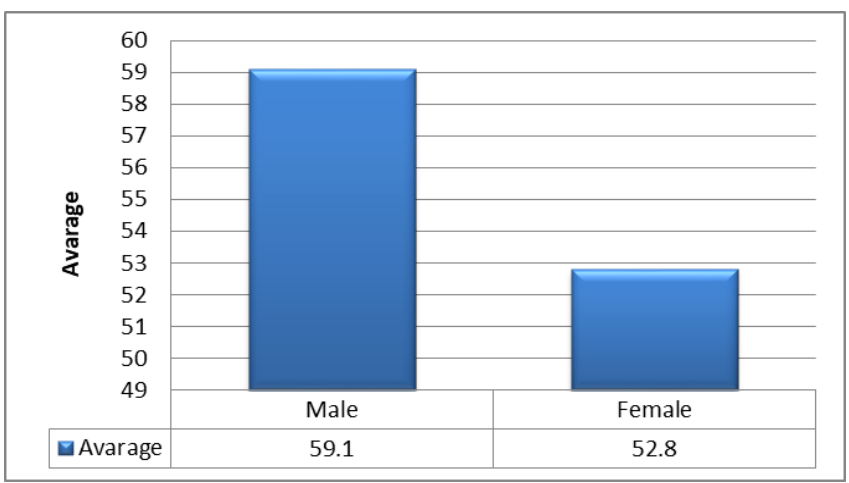

Figure 11. Average critical thinking skills by gender 
The average result of critical thinking skills by gender (male and female) shows a significant difference. This is because male students identify using the facts given in the questions clearly, logically, concisely, effectively, and efficiently, and male students identify problems based on elements that are only related to the problem. In contrast to women, if they identify using the facts given in the questions in a clear, logical, detailed, and complete manner, whether they will be used to work on the questions or not. So there is a difference between male and female students, which are able to identify problems and understand the questions in the question. This can be seen from the ability to write down the known elements of the question and those asked in the question correctly. These findings are in accordance with research conducted by Rubin (Cahyono, 2017), which shows no significant difference between men and women in the aspect of intelligence in general. However, in certain aspects, there can be differences between boys and girls.

\section{Student response questionnaire}

Based on the results of filling out a questionnaire by students regarding problem-based learning models and students' critical thinking skills. The following are the results of interviews conducted with students.

Table 1. Student's questionnaire on critical thinking skills

\begin{tabular}{|c|c|c|c|}
\hline No. & Questions & Yes & No \\
\hline 1 & Do you like physics & 54 & 63 \\
\hline 2 & Do you think dynamic electricity is important to understand? & 100 & 0 \\
\hline 3 & Do you think the subject of dynamic electricity is difficult to understand? & 92 & 8 \\
\hline 4 & $\begin{array}{l}\text { Do teachers often use the lecture method compared to experimental-based learning in the } \\
\text { laboratory in physics learning? }\end{array}$ & 81 & 19 \\
\hline 5 & Have you ever done any learning activities for improving critical thinking skills? & 79 & 22 \\
\hline 6 & Have you ever been trained with critical thinking skills test questions? & 65 & 36 \\
\hline 7 & Do you have difficulty when you have to answer the test questions? Critical thinking skills? & 83 & 19 \\
\hline 8 & Do you like the method used by the teacher in learning physics? & 68 & 32 \\
\hline 9 & Do you like online learning during a pandemic Covid-19 going on? & 8 & 92 \\
\hline 10 & Have you ever been trained by a teacher to use PhET in physics lessons? & 48 & 52 \\
\hline
\end{tabular}

The table above shows that students' responses to critical thinking skills are that most of them like physics and think that dynamic electricity needs to be studied. However, many students say that dynamic electricity is difficult to learn and understand because teachers often use this method. Lectures in teaching and never doing an experiment in the laboratory, especially during this pandemic. Some of the students have also done practice questions to improve critical thinking skills, but some students still have difficulty when given critical thinking questions. Students themselves also like the lecture method given by educators when learning takes place. Still, some do not like the method, especially during this pandemic.
Students have also never been trained to conduct experiments using virtual laboratories because educators have not used PhET. Therefore, educators need to find alternatives to improve their critical thinking skills.

\section{Teacher Interviews}

Based on the results of interviews with the physics teacher concerned regarding problem-based learning models and students' critical thinking skills. The following are the results of interviews conducted with teachers.

Table 2. Results of Interviews with Teachers

\begin{tabular}{lll}
\hline No & Interview Questions & Answers/Responses \\
\hline 1 & $\begin{array}{l}\text { How do you usually teach Physics concepts, } \\
\text { especially on dynamic electricity? }\end{array}$ & $\begin{array}{l}\text { Provide material from youtube, then invite discussion through google } \\
\text { classroom, google meet, or WhatsApp group with the lecture method }\end{array}$ \\
2 & $\begin{array}{l}\text { Have you ever carried out physics learning by } \\
\text { training students' critical thinking skills? }\end{array}$ & $\begin{array}{l}\text { It is rarely done because critical thinking skills require an interesting } \\
\text { learning model to foster students' critical thinking processes. And also, } \\
\text { not all of the classes that I hold are enthusiastic about physics lessons, } \\
\text { especially on electricity }\end{array}$ \\
3 & $\begin{array}{l}\text { Have you ever given questions to capture } \\
\text { students' critical thinking skills? }\end{array}$ & $\begin{array}{l}\text { Very rarely, because the critical thinking skills themselves use high } \\
\text { indicators. And less effective, if given to students who lack interest in } \\
\text { physics. }\end{array}$ \\
& $\begin{array}{l}\text { According to your mother, how are the efforts } \\
\text { made in learning to improve students' critical provide an interesting learning model so that the interest of } \\
\text { students increases. Not only that, the problems presented must also be }\end{array}$ \\
\hline
\end{tabular}




\begin{tabular}{|c|c|c|}
\hline No & Interview Questions & Answers/Responses \\
\hline & thinking skills? & interesting so that students have the curiosity to investigate them. \\
\hline 5 & $\begin{array}{l}\text { How do you respond to the profile of } \\
\text { students' critical thinking skills conducted by } \\
\text { researchers? }\end{array}$ & $\begin{array}{l}\text { Very good, because at this time critical thinking is very necessary and } \\
\text { can also be a reference for teaching. }\end{array}$ \\
\hline 6 & $\begin{array}{l}\text { What is your opinion of the problem-based } \\
\text { learning (PBL) model assisted by physics } \\
\text { education technology (PhET) as a virtual } \\
\text { laboratory to improve critical thinking skills? }\end{array}$ & $\begin{array}{l}\text { Very well, this learning model is suitable for the purpose of students' } \\
\text { critical thinking, because students' skills also tend to be low. Therefore, } \\
\text { with this learning method, students will be enthusiastic, because of the } \\
\text { new learning model. }\end{array}$ \\
\hline
\end{tabular}

Table 2 shows the results of interviews that teachers do not always follow the design of the learning implementation that is made. This is because the teacher adapts to the conditions during the learning process so that critical thinking skills are categorized as moderate. Critical thinking skills are important to be trained because critical thinking is so important that it becomes a matter of concern for educators and researchers. Menurut (Facione, 2015), sebagai pengaturan diri dalam memutuskan (menilai) sesuatu yang menghasilkan interpretasi, analisis, evaluasi, dan kesimpulan, serta paparan menggunakan bukti, konsep, metodologi, kriteria, atau pertimbangan kontekstual yang menjadi dasar keputusan tersebut. In addition, critical thinking is also important as an inquiry tool. Apart from the importance of critical thinking, critical thinking is very useful in making a person more independent, confident and solve problems more wisely. Therefore, improving the critical thinking process can be done with varied learning models.

Based on the research that has been done, it can be seen that some students are less precise in answering and solving critical thinking skills questions with indicators of analysis, evaluation, interpretation, and inference. The average results are less than satisfactory. Therefore, the level of students' critical thinking skills is in the medium category. However, nowadays, critical thinking skills are needed because they can be a reference in facing challenges and problems that arise in the future. Critical thinking skills are one of the important elements needed by students to become the main focus in education.

Then the number of students who do not understand this dynamic electricity material so that students' skills in solving problems are not optimal. Several factors can be identified that cause student to have difficulty completing students' critical thinking skills tests, namely learning methods used by teachers tend to use lecture methods and lack of practice of critical thinking skills tests. This causes the learning process to be not optimal, and the learning goal is not achieved. Therefore, teachers must replace the lecture learning model with a more varied learning model, such as problem-based learning (PBL). The PBL learning model is very suitable to be applied in senior high school because the learning model is complex and can improve critical thinking skills. This is in line with Hosnan's opinion (Farisi et al., 2017), which states that the main purpose of the PBL model is not to deliver most of the knowledge to students but rather to develop critical thinking skills and problem-solving. And also, students do not know about PhET because teachers have not implemented online experiments using PhET to students.

The research analysis results presented can be useful for assessing the effectiveness of the PBL learning model Assisted by PhET to improve critical thinking skills. The selected research includes research that was researched in 2017. The summary of the relevant research analysis can be seen in table 3 .

Table 3. Review Study of the last five years

\begin{tabular}{|c|c|c|}
\hline Author (Year) & Research Title & Finding \\
\hline $\begin{array}{l}\text { - Juhari, T., } \\
\text { Hikmawati, \& } \\
\text { Wahyudi } \\
\text { (2016) }\end{array}$ & $\begin{array}{l}\text { - The influence of the media- } \\
\text { based learning model assisted } \\
\text { by Media Phet on the learning } \\
\text { outcomes of physics students } \\
\text { of class X SMAN } 1 \\
\text { Gunungsari r 2015/2016 } \\
\text { academic year }\end{array}$ & $\begin{array}{l}\text { - This research aims to find out the effect of the problem-based } \\
\text { learning model with PhET media on the student's physics results. } \\
\text { This research is a quasi-experiment with a nonequivalent control } \\
\text { group design. } \\
\text { So can be concluded that there is an effect of a problem-based } \\
\text { learning model with PhET media on the student's physics results. }\end{array}$ \\
\hline $\begin{array}{l}\text { - Farisi, A., } \\
\text { Hamid, A., \& } \\
\text { Melvina } \\
\text { (2017) }\end{array}$ & $\begin{array}{l}\text { - Effect of Learning Model } \\
\text { Problem Based Learning } \\
\text { Against Thinking Skills } \\
\text { Critical in Improving Student } \\
\text { Results In concept } \\
\text { Temperature And Heat }\end{array}$ & $\begin{array}{l}\text { - This research aims to see the influence of the Problem Based } \\
\text { Learning (PBL) learning model on student critical thinking skills } \\
\text { The approach used is quantitative in the form of experimental } \\
\text { research. The sampling technique used the purposive sampling } \\
\text { technique } \\
\text { The conclusion of this research is the influence of using the Problem }\end{array}$ \\
\hline
\end{tabular}




\begin{tabular}{|c|c|c|}
\hline Author (Year) & Research Title & Finding \\
\hline $\begin{array}{l}\text { - Agusmin, R., } \\
\text { \& Rohadi, N. } \\
\text { (2018) }\end{array}$ & $\begin{array}{l}\text { - Increased student motivation } \\
\text { and learning outcomes with } \\
\text { the Problem Based Learning } \\
\text { model assisted by PhET } \\
\text { simulated in class XI IPA-C } \\
\text { SMAN } 6 \text { Bengkulu City. }\end{array}$ & $\begin{array}{l}\text { Based Learning (PBL) learning model on students' critical thinking } \\
\text { skills. } \\
\text { - This study includes classroom action research that aims to } \\
\text { determine the increase in learning activities, learning motivation, } \\
\text { and student learning outcomes. } \\
\text { This type of research is classroom action research, with the data } \\
\text { collection techniques used are observation, questionnaires, and } \\
\text { cycle tests. } \\
\text { Based on the study results, it can be concluded that the } \\
\text { implementation of the Problem Based Learning Model Assisted } \\
\text { Simulation PhET can increase learning activities, learning } \\
\text { motivation, and student learning outcomes. }\end{array}$ \\
\hline $\begin{array}{l}\text { - Gusniar, \& } \\
\text { Juliani, R. } \\
\text { (2019) }\end{array}$ & $\begin{array}{l}\text { - Analysis of the application of } \\
\text { the Problem Based Learning } \\
\text { (PBL) learning model assisted } \\
\text { by Media PhET in } 1 \text { Public } \\
\text { High School Mirror }\end{array}$ & $\begin{array}{l}\text { - The research aims to determine the increase in learning outcomes } \\
\text { by applying the PBL model assisted by Media PhET. } \\
\text { This type of research uses quasi-experiments with the design of one } \\
\text { group pretest-posttest, with instruments used to collect cognitive } \\
\text { learning outcomes in the study of } 15 \text { multiple choice questions with } \\
\text { five options that have been validated while learning outcomes of } \\
\text { skills and activities are taken using the assessment sheet through } \\
\text { observation observer. }\end{array}$ \\
\hline $\begin{array}{l}\text { - Ramadani, M. } \\
\text { E., \& Nana } \\
\text { (2020) }\end{array}$ & $\begin{array}{l}\text { - Application of Problem Based } \\
\text { Learning Daunt Virtual Lab } \\
\text { PhET on physics learning to } \\
\text { improve understanding of the } \\
\text { concept of high school } \\
\text { students: Literature Review }\end{array}$ & $\begin{array}{l}\text { The results of data analysis obtained learning outcomes of students } \\
\text { using the PBL model experienced an increase in both cognitive, } \\
\text { psychomotor, and activity where cognitive increases. } \\
\text { - The research aims to describe the application of the Problem Based } \\
\text { Learning (PBL) model based on Virtual Laboratory PhET in physics } \\
\text { learning as an innovation to improve the understanding of concepts } \\
\text { in high school students. } \\
\text { The method used to analyze the application of Problem Based } \\
\text { Learning Virtual Lab PhET in physics learning to improve the } \\
\text { understanding of the concept of high school students namely } \\
\text { literature studies. } \\
\text { The results of this writing show that the application of the Problem } \\
\text { Based Learning model assisted by Virtual Laboratory Phet as } \\
\text { learning innovation can solve the problems encountered in the } \\
\text { teaching and learning process in the classroom. }\end{array}$ \\
\hline
\end{tabular}

\section{Conclusion}

Based on the results of research and discussion, we can conclude that the critical thinking skills of students of the senior public school Surabaya were at a moderate level. Based on student questionnaires and teacher interviews, it can be seen that educators in every school needed to train students' critical thinking skills, and it was necessary to change the applied learning model. Therefore, based on the study's conclusion, the researchers suggest changing the innovative and creative learning model into an index based on critical thinking skills, namely improving students' critical thinking skills through the PBL learning model assisted by PhET. The main problem is improving dynamic electrical thinking skills.

\section{Acknowledgments}

Thank you for Dr. Mugono, S.Pd, M.Pd as Principal of SMAN 8 Surabaya, which has given permission to conduct research, then to the physics teacher Mrs. Hj. Noer Pudji Rahayu, S.Pd, M.Pd and students of class XI SMAN 8 Surabaya and all parties who have assisted in supporting this study's completion.

\section{References}

Al-Idrus, S.Q.J., Hikmawati., \& Wahyudi. (2015). Pengaruh Model Pembelajaran Berbasis Masalah Berbantu Video Kartun Terhadap Hasil Belajar Fisika Siswa Kelas XI SMAN 1 Sikur Tahun Ajaran 2014/2015. Jurnal Pijar MIPA, 26-30. DOI: http://dx.doi.org/10.29303/ipm.v10i1.12 [Indonesian]

Cahyono, B. (2017). Analisis Ketrampilan Berfikir Kritis Dalam Memecahkan Masalah Ditinjau Perbedaan Gender. Aksioma, 8(1), 52. https://doi.org/https://doi.org/10.26877/aks.v $\underline{8 i 1.1510 \text { [Indonesian] }}$ 
Depdiknas. (2003). Kurikulum 2041: Standar Kompetensi, Mata Pelajaran Fisika, Sekolah Menengah Atas dan Madrasah Aliyah. Jakarta. [Indonesian]

Facione, P. (2015). Critical Thinking: What It Is and Why It Counts. Insight Assessment.

Farisi, A., Hamid, A., \& Melvina (2017). Pengaruh Model Problem Based Learning Terhadap Kemampuan berpikir Kritis dalam Meningkatkan Hasil Belajar Siswa. Jurnal Ilmiah Mahasiswa Pendidikan Fisika, 2(3). 283-287. Retrieved from: http://www.jim.unsyiah.ac.id/pendidikanfisika/article/view/4979 [Indonesian]

Ismayawati, B., Purwoko A.A., \& Muntari (2016). Pengaruh Model Pembelajaran Berbasis Masalah (Pbm) Dalam Setting Pembelajaran Kooperatif Tipe TGT dan GI Terhadap Keterampilan Berpikir Kritis dan Hasil Belajar Kimia Peserta Didik SMAN 1 Aikmel. Jurnal Penelitian Pendidikan IPA. 2(1). doi: https://doi.org/10.29303/jppipa.v2i1.33 [Indonesian]

Latifa, B., Verawati, N., \& Harjono, A. (2017). Pengaruh Model Learning Cycle 5E (Engage, Explore, Explain, Elaboration, \& Evaluate) Terhadap Kemampuan Berpikir Kritis Peserta Didik Kelas X MAN 1 Mataram. Jurnal Pendidikan Fisika dan Teknologi, 3(1), 61-67. doi:http://dx.doi.org/10.29303/jpft.v3i1.325 [Indonesian]

Maryati, I. (2018). Penerapan Model Pembelajaran Berbasis Masalah Pada Materi Pola Bilangan Di Kelas Vii Sekolah Menengah Dasar. Mosharafa, 7(1). 64-65. doi: https://doi.org/10.31980/mosharafa.v7i1.342 [Indonesian]

Pradana, S., Parno, P., \& Handayanto, S. (2017). Pengembangan tes kemampuan berpikir kritis pada materi Optik Geometri untuk mahasiswa Fisika. Jurnal Penelitian dan Evaluasi Pendidikan, 21(1), 51-64. doi:https://doi.org/10.21831/pep.v21i1.13139 [Indonesian]

Prasanti, D. (2018). Penggunaan Media Komunikasi Bagi Remaja Perempuan Dalam Pencarian Informasi Kesehatan. Jurnal Lontar, 6(1). 13-21. doi https://doi.org/10.30656/lontar.v6i1.645 [Indonesian]

Qurniati, D.A., Andayani, Y., \& Muntari, M. (2015). Peningkatan Keterampilan Berpikir Kritis Melalui Model Pembelajaran Discovery Learning. Jurnal Penelitian Pendidikan IPA, 1(2). 58-69. doi: https://doi.org/10.29303/jppipa.v1i2.20 [Indonesian]
Rahayu, S.K. (2017). Perpajakan Konsep dan Aspek Formal. Bandung: Rekayasa Sains. [Indonesian]

Rosa, N., \& Pujiati, A. (2017). Pengaruh Model Pembelajaran Berbasis Masalah Terhadap Kemampuan Berpikir Kritis dan Kemampuan Berpikir Kreatif. Formatif: Jurnal Ilmiah Pendidikan MIPA, 6(3). doi:http://dx.doi.org/10.30998/formatif.v6i3.99 0. [Indonesian]

Rositasari, D., Saridewi, N., \& Agung, S. (2015). Pengembangan Tes Diagnostik Two-Tier Untuk Mendeteksi Miskonsepsi Siswa Sma Pada Topik Asam-Basa. Edusains, 6(2), 169 - 176. doi:https://doi.org/10.15408/es.v6i2.1148. [Indonesian]

Sugiyono. (2017). Metode Penelitian Kuantitatif, Kualitatif, dan RED. Bandung: Alfabeta. [Indonesian]

Zahara, S.R., Yusrizal., \& Rahwanto, A. (2015). Pengaruh Penggunaan Media Komputer Berbasis Simulasi Physics Education Technology (PhET) Terhadap Hasil Belajar Dan Keterampilan Berfikir Kritis Siswa Pada Materi Fluida Statis. Jurnal Pendidikan Sains Indonesia, 3(1). 251-258. Retrieved from: http://jurnal.unsyiah.ac.id/JPSI/article/view/7 $\underline{671}$ [Indonesian] 